\title{
Proposal of an alternative technology for dairy farming in the North Caucasus
}

\author{
A.B. Baragunov ${ }^{1, *}$, E.A. Kushaeva ${ }^{1}$, M.M. Hamokov ${ }^{1}$, and A.V. Sagatelian ${ }^{2}$ \\ ${ }^{1}$ Kabardino-Balkarian State Agrarian University, Nalchik, Russia, 360020 \\ ${ }^{2}$ State Veterinary Service of the Republic of Abkhazia, Sukhum, Abkhazia, 384900
}

\begin{abstract}
The article presents the results of research work in the field of dairy farming. During the study, shortcomings in the technology and technical means of machine milking and primary processing of cow's milk in the mountainous conditions of farming in the North Caucasus are revealed. The main producers are households, individual entrepreneurs and peasant (farm) households. An alternative technology of machine milking and primary processing of milk with energy-saving technical means of machine milking, manure removal, the use of non-traditional energy sources, assembled into a technological line for milk production is proposed. The results of comparative production tests of a milking machine for operation in foothill and mountainous regions are presented, a characteristic feature of which is operation without breaking the operating mode at elevations above a thousand meters above sea level. The results confirm the advantage of the proposed design in terms of milk excretion rate, productivity, milk quality in terms of fat content, low injury to the milking livestock when using the development. Energy indicators of the advantages of the technology for collecting and utilizing manure with obtaining an additional energy carrier and high-quality organic fertilizer are also given. The proposed technology provides for measures and technical means for the care of the pasture territory in order to exclude violations of the environment and vegetation cover of the rich forbs of the North Caucasian mountain pastures.
\end{abstract}

The North Caucasian region possesses rich pasture lands containing naturally growing herbaceous vegetation rich in valuable ecologically pure plants [1]. This natural resource is not used rationally for the development of the livestock sector, in particular, the dairy sector. There are objective reasons for this phenomenon of modern agriculture in the region, associated with various factors. One of the factors behind the underdevelopment of the above natural resource is low scientific support of technology and technical means of successful milk production in the foothill and mountain conditions of management.

After monitoring all forms of producers in the region's industry, it was revealed that the main milk producers are small forms of farming - households, individual entrepreneurs and peasant (farmer) households [2-5]. Also, an analysis of the technical equipment of the main manufacturers indicates that they are not adapted to the characteristics of the region. Taking

*Corresponding author: baragun_albert@mail.ru 
into account the peculiarities of production conditions, there is no scientifically grounded technology for production of high-quality high-grade milk, including machine milking, primary processing of milk and related technological operations that ensure the full cycle of this type of farming [6-9].

These types of farms use technology and technical means originally created for the conditions of most of the farms of the country's territory, located on flat terrain (at an altitude of up to $1000 \mathrm{~m}$ above sea level). The revealed feature of inconsistency of technical means in mountainous conditions of management negatively affects the output final indicators of production: productive health of the dairy herd, milk quality, milk yield. To solve this problem, an alternative technology of dairy farming is proposed for the conditions of the North Caucasus (Fig. 1).

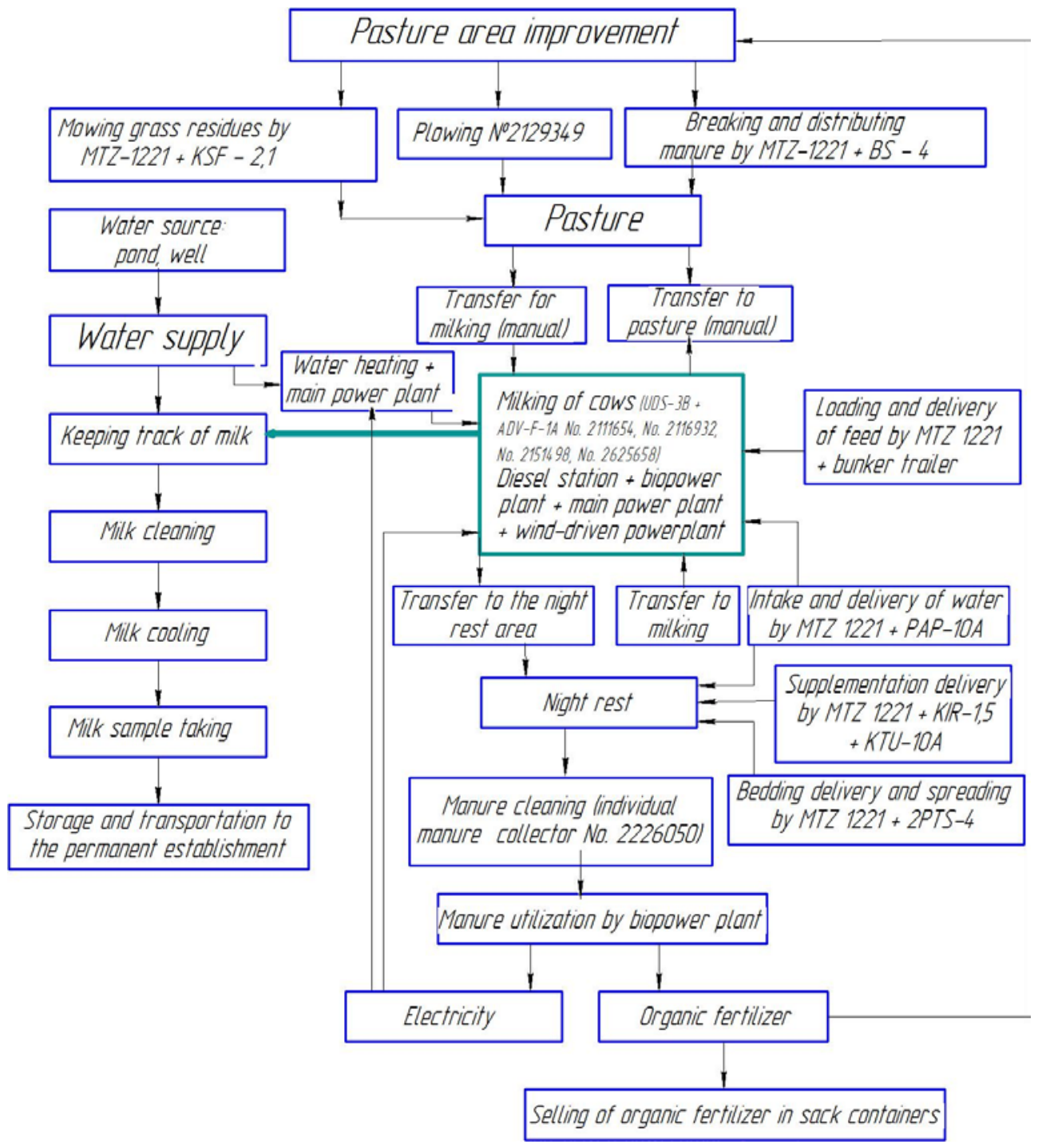

Fig. 1. Diagram of milk production technology in mountains

The presented diagram of milk production technology with a transhumant-tie-up dairy herd in the warm season - April-October on mountain pastures, in the cold season - 
November-March, the livestock is placed on the farm. It is proposed to introduce the milking machine ADV-F-1A (patents No. 2111654, No. 2151498, No. 2216932, No. 2625658, No. 2719750), which has a number of advantages in mountainous conditions of management (see Fig. 2, 3, 4, 5) [10], into the general production line.

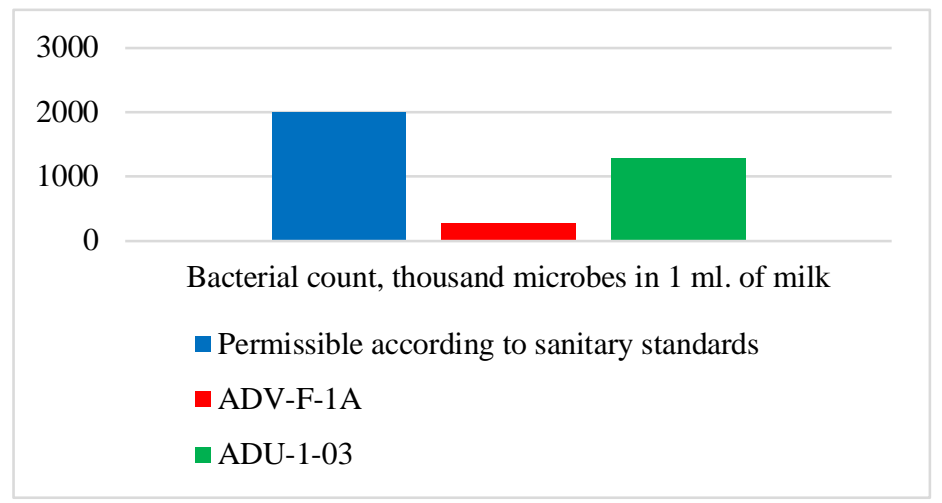

Fig. 2. Milk quality in terms of bacterial count

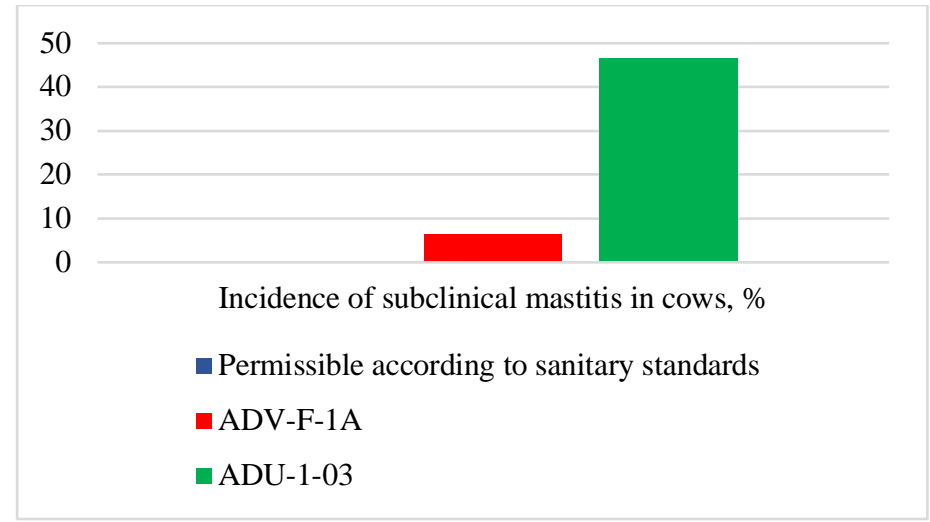

Fig. 3. Udder disease from milking machines

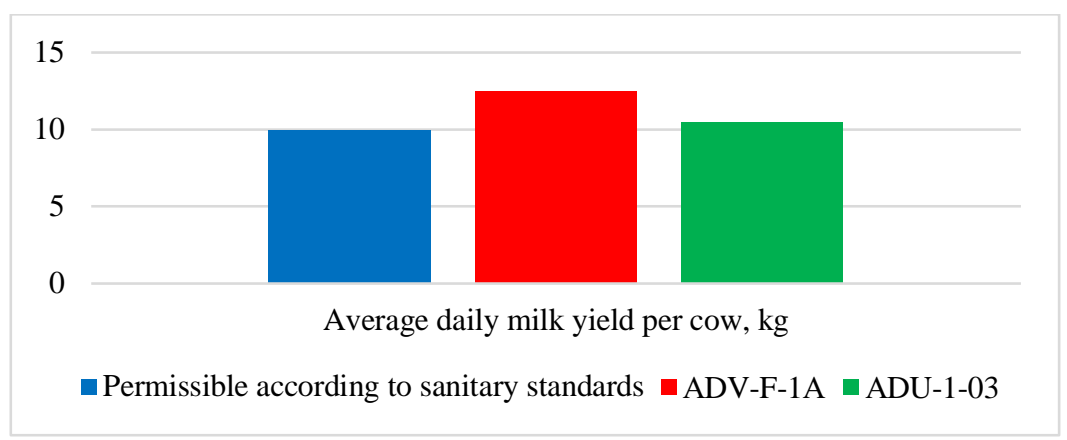

Fig. 4. Milk yield at a steady milk withdrawal mode 


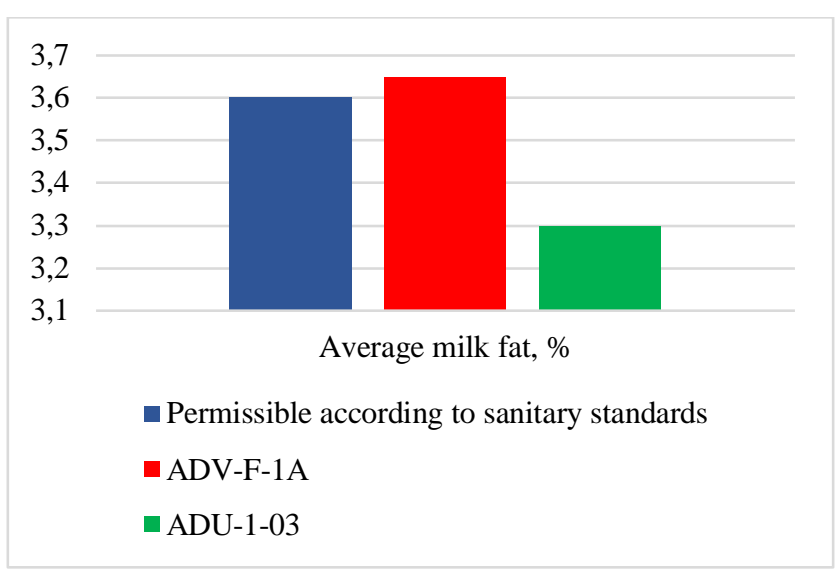

Fig. 5. Comparison of milk composition by fat content

On the pasture, a mobile milking and pasture center is organized near the herd grazing, with the installation of a shelter for night rest, a vacuum installation, milk processing equipment, providing mobile power plants (diesel generator; solar power plants; wind power, hydropower, bioenergy plants). The bioenergy plant enables you to combine generation of electricity and disposal of manure. In the end, it additionally produces high-quality organic fertilizer, with the possibility of using it later on the territory of the same pasture and farmland of the farm, and the surplus can be sold to third-party farms.

In the cold period of tie-up housing, it is possible to use energy-saving means for collecting manure (No. 2226050), which makes it possible to reduce the significant capacity of technical means for maintaining cleanliness, collecting and removing manure from barns. It is proposed to combine the bioenergy installation, which allows the rational use of livestock waste.

Comparative production tests [11] of milking machines gave the results of an hourly productivity advantage in machine milking of cows by 15 - 20\%, in comparison with serial ones. Annual energy saving is at least 3.0 thousand kWh per year; there is an increase in the rate of lactation, the process of machine lactation of the entire herd is completed 18 minutes faster (with a herd of 100 heads), labor productivity rises in 1 hour of main time by 8 heads; there is an increase in the productivity of cows (see Fig. 4, 5); there is reduced bacterial count (see Fig. 2) and mechanical contamination of milk; the number of cases of cow diseases with subclinical mastitis is reduced by $40 \%$ (see Fig. 3) [10].

\section{Conclusions}

1. Monitoring of milk producers' farms in the North Caucasus is carried out.

2. The technical means of machine milking, which have adaptive qualities to changes in barometric pressure (mountain conditions) without interruptions in the operating mode, which have a gentle milk removal method and increase productivity of the dairy herd (patents No. 2111654, No. 2151498, No. 2216932, No. 2625658, No. 2719750) are proposed.

3 . It is recommended to include energy-saving means of manure collection in the proposed technological line, releasing energy-intensive technical means of manure removal (patent No. 2226050).

4. The use of power supply facilities with the use of non-traditional energy sources enables to save energy consumption of the production process at the rate of at least 3.0 thousand $\mathrm{kWh}$ per year. 
5. The use of a bioenergy plant will allow to utilize wastes of the production process, preserve the environment and obtain high-quality organic fertilizers (patent No. 174157).

6. Introduction of an alternative technological line for milk production will make it possible to obtain high quality milk with an economically attractive effect.

\section{References}

1. Baragunov A.B., Krasnova A.Yu. Mechanization of milking and primary processing of milk in mountainous conditions (monograph). - Nalchik: KBGAU, 2017. 232 p.

2. Krasnov I.N., Miroshnikova V.V. Organization of machine milking of cows on modular farms. Selskiy mekhanizator [Rural mechanic]. 2017. - No. 9. - pp. 18-19

3. Kilchukova O.Kh., Fiapshev A.G. and Yurov A.I. Alternative energy in the North Caucasus // Vestnik VIESKh [Bulletin of All-Russian Scientific Research Institute for Electrification of Agriculture]. 2014. No. 4 (17). pp. 16-19.

4. Ulimbashev M.B. Influence of heredity on histological structure and microstructure of the mammary gland of cows. Doklady Rossiyskoy akademii selskohozyaystvennykh nauk [Reports of the Russian Academy of Agricultural Sciences]. 2009. No. 5. pp. 4345.

5. Krasnov I.N., Krasnova A.Yu. \& Miroshnikova V.V. Roles of milking motives in cows’ milk discharging-EurAsian Journal of BioSciences Eurasia J Biosci 12, 83-87 (2018)

6. Krasnov I.N., Krasnova A.Yu., Miroschnikova V.V. \& Tolstoukhova T.N. Energy saving in milk pasterization processes hydrodynamic heaters use - PlantArchives Vol.18 N 2 2, 2018 pp. 2593-2599.

7. Gerasimova O.A. Increasing the efficiency of milk production with pasture keeping of cows // Izvestiya Velikolukskoy GSKhA [Bulletin of Velikiye Luki State Agricultural Academy] - 2017. (anniversary edition) p. 34-40

8. Krasnov I.N., Kapustin I.V., Krasnova A.Yu. and Miroshnikova V.V. Milk production on a modular farm with environmentally friendly technology. Nauchno-prakticheskiy zhurnal 'Vestnik APK Stavropolya' [Scientific and practical journal 'Bulletin of the agro-industrial complex of Stavropol']. 2012. - No. 2. - pp. 45-50

9. Apazhev A.K., Shekikhachev Ya.A., Khazhmetov L.M., Fiapshev A.G., Baragunov A.B., Khamokov M.M. and Kilchukova O.Kh. Innovative technology and technical means for the disposal of manure and dung. Vestnik selskokhozyaystvennogo konsultirovaniya [Bulletin of agricultural consulting]. Special issue No. 2 - Luchshie innovatsii $v$ APK [The best innovations in the agro-industrial complex]. No. 4. - 2015 pp. 42-48.

10. Baragunov B.Ya., Baragunov A.B. Energy-saving means of mechanization of collecting cow excrements. Proceedings of the 4th International Scientific and Technical Conference. GNU VIESKh Part 3. - Moscow, 2004. - pp. 159-162.

11. Miroshnikova V.V., Krasnov I.N. Improvement of livestock production technology on a closed-cycle modular dairy farm. Izvestiya Gorskogo gosudarstvennogo agrarnogo universiteta [Bulletin of Gorskiy State Agrarian University]. 2016.Vol. 53. No. 4. pp. 92-98. 